\title{
Pengaruh Visualisasi Foto OOTD (Outfit of The Day) Selebgram Sebagai Strategi Promosi Produk Fashion Terhadap Persepsi Wanita
}

\author{
Ekariana Fitrina Irawan dan Asep Ramdhan \\ Magister Desain, Fakultas Seni Rupa dan Desain, Institut Teknologi Bandung \\ e-mail: ekarianafirawan@gmail.com
}

\begin{abstract}
Abstrak-Instagram adalah media sosial yang populer digunakan sebagai media promosi online dalam pemasaran digital, khususnya untuk produk fashion. Belanja online sudah menjadi bagian dari keseharian masyarakat perkotaan terutama bagi generasi muda, khususnya wanita. Salah satu yang sedang menjadi tren dan dinilai paling menarik bagi konsumen wanita adalah visualisasi foto OOTD (outfit of the day) seorang selebgram yang mempromosikan produk fashion.Penelitian dilakukan untuk mengetahui seberapa besar pengaruh visualisasi foto OOTD (outfit of the day) seorang selebgram terhadap keefektivitasan membangun persepsi konsumen wanita sebagai bagian dari strategi promosi online sebuah produk fashion. Proses analisis dilakukan dengan metode kualitatif deskriptif. Studi dokumentasi, observasi online, dan kuesioner digital digunakan sebagai alat pengumpulan data yang kemudian hasilnya akan dipaparkan secara deskriptif dengan pendekatan teori media sosial menurut Rulli Nasrullah, serta teori male gaze menurut John Berger yang merupakan bagian dari studi budaya visual. Perkembangan budaya siber pada media sosial Instagram sebagai bentuk eksistensi individu dalam menciptakan citra diri, serta adanya unsur male gaze dan fan-culture yang merupakan realitas sosial dalam dunia siber tersebut, dinilai mampu mempengaruhi persepsi konsumen wanita dalam strategi pemasaran digital produk fashion di era industri $\mathbf{4 . 0}$ saat ini.
\end{abstract}

Kata Kunci: fashion,pemasaran digital, persepsi konsumen, dan selebgram

Abstract-Instagram is a social media that is popularly used as an online promotion media in digital marketing, especially for fashion products. Online shopping has become part of the daily life of urban communities, especially for the younger generation and women. One of the trends and considered the most attractive for female consumers is the visualization of an outfit of the day (OOTD) photo of a celebrity on Instagram who promotes fashion products. The research was conducted to find out how much the influence of the outfit of the day (OOTD) visualization of a celebrity photo on the effectiveness of building perceptions of female consumers as part of an online promotion strategy for a fashion product. The analysis process is carried out using descriptive qualitative methods. Documentation studies, online observations, and digital questionnaires are used as data collection tools which then will be explained descriptively by social media theory approach according to RulliNasrullah, as well as male gaze theory according to John Berger which is part of visual culture studies. The development of cyber culture on Instagram as a form of individual existence in creating selfimage, as well as the presence of male gaze and fan-culture elements which are a social realities in the cyber world, are considered capable of influencing the perception of female consumers in digital marketing strategies of fashion products in the current 4.0 industry era.
Keywords: fashion, digital marketing, consumer perception, and celebrity endorser

\section{PENDAHULUAN}

Fenomena keberadaan internet dewasa ini, sejak ditemukannya internet telah terjadi perubahan besar dalam komunikasi massa. Banyaknya serta beragamnya informasi di internet menjadi sumber informasi baru yang menarik khalayak media massa untuk perpindah dari media massa lama (old media) ke media baru (new media).New media dalam dunia online, khususnya media sosial, saat ini tidak hanya digunakan untuk saling berbagi informasi di antara penggunanya, namun juga digunakan sebagai platform untuk berdagang hingga iklan promosi penjualan berbagai macam produk, khususnya produk fashion. Belanja online telah menjadi gaya hidup, terutama bagi masyarakat perkotaan di era revolusi industri saat ini. Sebuah lembaga analisa, SumAll, menyatakan bahwa salah satu media sosial yang sedang menjadi trend dan paling efektif sebagai media promosi online adalah Instagram. Beberapa fitur dan keunggulan Instagram mendorong pertumbuhan pengguna yang luar biasa, yang akhirnya menjadikan Instagram sebagai pilihan para Digital Marketer untuk digunakan dalam aktivitas digital marketing-nya. Survey terbaru lembaga riset Snapcart di Januari 2018 mengungkapkan bahwa generasi muda dengan rentan usia 15-34 tahun menjadi pembelanja terbanyak di bidang e-commerce yakni sebanyak $80 \%$, dengan mayoritas konsumen belanja online berdasarkan gender adalah wanita dengan jumlah mencapai $65 \%$ [1].

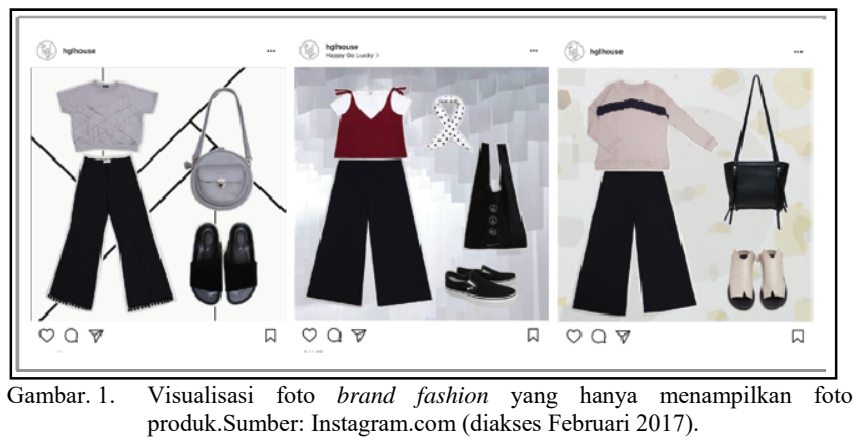

Perkembangan bisnis fashion di dunia online dibuktikan dengan banyaknya brand fashion lokal baru yang hadir dan menggunakan Instagram sebagai media promosi untuk memasarkan produknya. Berbagai macam gaya visual foto produk ditampilkan untuk menarik perhatian konsumen di Instagram, serta untuk mengangkat citra brand dari produk yang ditawarkan. Diantaranya ada visual foto yang hanya menampilkan produk fashion yang ditawarkan (Gambar 1), dan ada pula visual foto yang menampilkan seorang foto model yang berpose mengenakan produk fashion yang ditawarkan tersebut (Gambar 2). Selain itu, saat ini muncul istilah 'endorse' yang menjadi trend pada pengguna Instagram. 


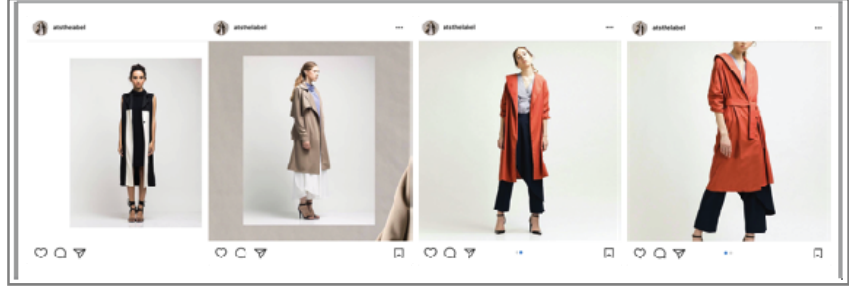

Gambar. 2. Visualisasi foto brand fashion yang menggunakan foto model.Sumber Instagram.com (diakses Februari 2017).

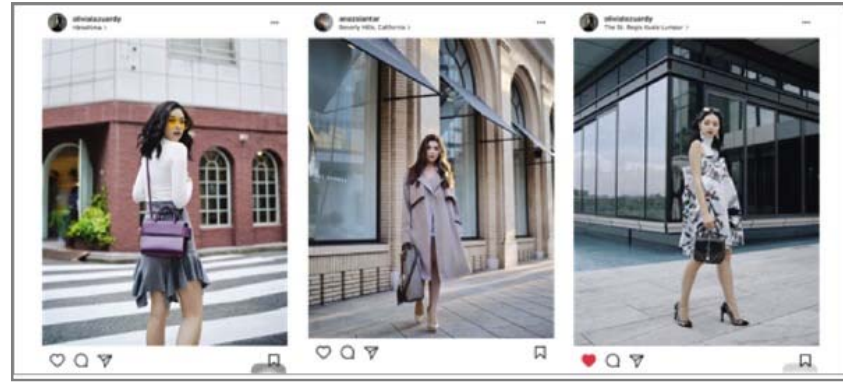

Gambar. 3. Visualisasi foto brand fashion yang menggunakan selebgram. Sumber Instagram.com (diakses Februari 2017).

Fenomena celebrity endorser, atau saat ini dikenal dengan istilah Selebgram, dalam strategi promosi online tidak lepas dari kreativitas selebgram tersebut dalam menampilkan visual yang unik dan menarik yang diunggah dalam galeri Instagramnya. Dari kreativitas para selebgram tersebutlah, akan diketahui segmen pasar yang dapat dituju oleh sebuah brand product. Selain itu kualitas visual yang disajikanpun menjadi faktor penting dalam membangun interaksi dengan para pengikut Instagram. Keefektivitasan pengaruh seorang selebgram terhadap brand yang dibawakan bukan hanya dilihat dari jumlah followers-nya saja, namun harus juga berbanding lurus dengan jumlah interaksi yang dibangun dengan para followers-nya tersebut. Hal itu dapat dilihat dari banyaknya jumlah 'like' dan 'comment' pada setiap foto atau video yang diunggah. Hasil penelitian yang dilakukan oleh Social Buzz tahun 2018, juga menyebutkan bahwa para pemasar saat ini lebih memilih 'selebriti internet' dibandingkan artis untuk bekerja sama dalam mempromosikan produk, dikarenakan faktor engagement rate serta karakteristik dan gaya hidup selebgramyang cenderung sesuai dengan identitas suatu merek [2].

Dalam strategi promosi sebuah produk fashion, masyarakat lebih tertarik melihat foto seorang selebgram yang menampilkan foto OOTD atau outfit of the day (Gambar 3)dibandingkan dengan hanya melihat tampilan sebuah produkataupun penggunaan jasa model. Hal itu sesuai dengan data hasil kuesioner awal yang telah dilakukan secara online kepada 92 responden wanita pada tanggal 30 April 2018 mengenai ketertarikan secara visual yang kemudian berpengaruh terhadap minat pembelian. Visual foto OOTD menjadi trend di kalangan masyarakat pengguna media sosial Instagram, yang mana memperlihatkan tampilan visual foto pengguna dengan gaya fashion tertentu, dengan pose layaknya seorang model, dan situasi latar belakang foto yang memperlihatkan kegiatan yang dilakukan guna menambah nilai estetika pada foto diri tersebut. Apapun alasan yang ingin disampaikan oleh para pengguna secara umum bisa dikatakan bahwa fenomena foto diri adalah fenomena eksistensi diri di media sosial [3].

Beberapa penelitian terdahulu telah membahas fenomena endorsement sebagai strategi promosi sebuah produk, baik dilihat dari ranah studi management marketing, komunikasi, maupun psikologi. Namun belum ada penelitian yang membahas fenomena visualisasi foto OOTD selebgram tersebut dari pendekatan ilmu budaya visual. Oleh karena itu, timbul ketertarikan untuk meneliti seberapa besar pengaruh visual foto OOTD (outfit of the day) seorang selebgram dalam mempengaruhi persepsi wanita sebagai bagian dari strategi promosi online sebuah produk fashion pada media sosial Instagram, dilihat dari pendekatan teori media sosial menurut Rulli Nasrullah, serta teori male gaze menurut John Bergeryang merupakan bagian dari studi budaya visual.

\section{PENDEKATAN TEORI}

Pendekatan teori yang digunakan dalam penelitian ini adalah teori media sosial menurut Rulli Nasrullah dan male gaze menurut John Bergeryang merupakan bagian dari studi budaya visual.

\section{Media sosial}

Rulli Nasrullah dalam bukunya yang berjudul "Media Sosial", menjelaskan definisi media sosial adalah medium di internet yang memungkinkan pengguna merepresentasikan dirinya maupun berinteraksi, bekerja sama, berbagi, berkomunikasi dengan pengguna lain, dan membentuk ikatan sosial secara virtual. Menurut Saxena [4], situs jejaring sosial adalah media sosial yang paling populer. Media sosial tersebut memungkinkan anggota untuk berinteraksi satu sama lain. Interaksi terjadi tidak hanya pada pesan teks, tetapi juga foto dan video yang mungkin menarik perhatian pengguna lain. Semua posting (publikasi) merupakan real time, memungkinkan anggota untuk berbagi informasi seperti apa yang terjadi. Adapun situs jejaring sosial yang cukup populer di Indonesia saat ini, antara lain Instagram.

\section{Male Gaze}

Male Gaze adalah respon kaum feminis terhadap sikap voyeurism pria melihat wanita. Laura Mulvey mengemukakan teorinya tentang 'Male Gaze' dan 'Visual Pleasure and the Narrative Cinema' dalam Essay tahun 1975. Male Gaze berkaitan dengan cara bagaimana audience melihat pada yang ditampilkan [5]. Male gaze menurut John Berger[6], adalah tentang pria melihat wanita, dan wanita melihat dirinya sendiri. Seorang wanita selalu berpikir tentang penampilannya dan bagaimana ia terlihat di depan pria. "Man act, Women appear". Bagi kaum feminis, Male Gaze dapat dilihat dalam 3 cara yakni bagaimana pria melihat wanita, bagaimana wanita melihat dirinya sendiri, dan bagaimana wanita melihat wanita lainnya.

Proses analisis dilakukan dengan metode kualitatif deskriptif. Proses pencarian data dilakukan dengan melakukan studi dokumentasi dan observasi secara online pada media sosial Instagram, disertai dengan membagikan kuesioner digital melalui program Google Form kepada 92 responden wanita dengan kategori usia 23-30 tahun yang bertempat tinggal di kota Bandung dan Jakarta. Hasil analisis kemudian akan dipaparkan secara kualitatif deskriptif dengan pendekatan teori media sosial menurut Rulli Nasrullah, serta teori male gazemenurut John Berger tersebut yang merupakan bagian dari studi budaya visual.

\section{HASIL DAN PEMBAHASAN}

Jumlah Anda lebih tertarik untuk membeli produk fashion/pakaian karena melihat foto yang nomor berapa?

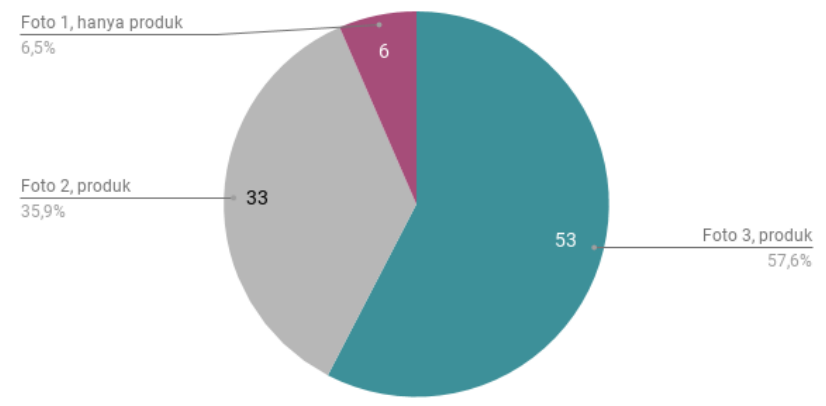

Gambar. 4. Diagram hasil kuesioner mengenai ketertarikan visual yang mempengaruh minat beli konsumen wanita. Sumber: Google Form (diakses Mei 2018). 


\section{Hasil kuesioner}

Dalam strategi promosi sebuah produk fashion, konsumen wanita lebih tertarik melihat foto seorang selebgram yang menampilkan foto OOTD (outfit of the day) dibandingkan dengan hanya melihat tampilan sebuah produk ataupun penggunaan jasa seorang model. Hal itu sesuai dengan data hasil kuesioner penelitian yang telah dilakukan secara online kepada 92 responden wanita pada tanggal 30 April 2018 mengenai ketertarikan secara visual yang kemudian berpengaruh terhadap minat pembelian (Gambar 4).

Dengan memberikan perbandingan 3 jenis visual foto produk fashion wanita yang ada pada media sosial Instagram berikut (Gambar 5), berdasarkan presentase sebesar 57,6\% dari total responden menyatakan foto diri seorang selebgram dalam menampilkan produk fashion dinilai paling menarik.

Ada beberapa faktor yang mendasari jawaban responden tersebut, antara lain sebagai berikut:

a. Visual foto produk fashion yang digunakan oleh selebgram terlihat lebih realistis, baik secara postur tubuh maupun lokasi pemakaian produk yang sesuai dengan keseharian responden.

b. Visual foto selebgram dapat memberikan informasi yang lebih jelas tentang produk.

c. Visual foto selebgram dapat memberikan inspirasi gaya berbusana.

d. Dengan digunakan oleh selebgram, tercipta persepsi bahwa produk fashion tersebut adalah jenis produk fashion yang sedang hits (kekinian).

e. Tampilan visual foto secara keseluruhan dinilai lebih estetik, sehingga menarik untuk dipandang.

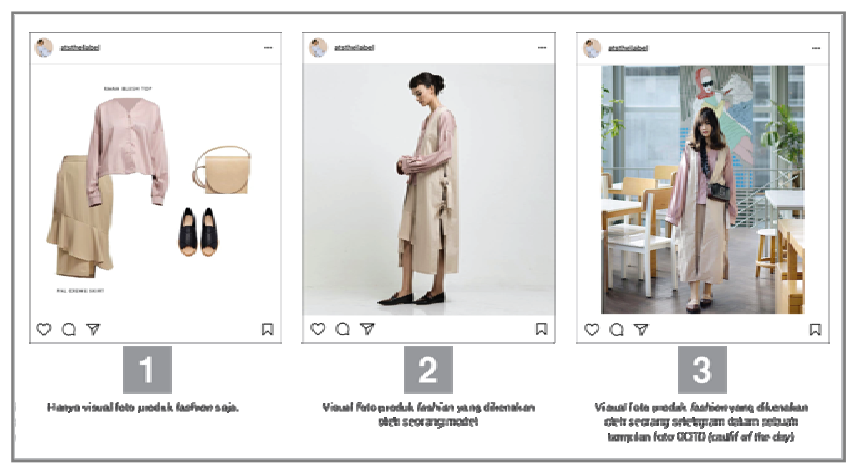

Gambar. 5. Perbandingan visualisasi foto produk fashion yang digunakan dalam pertanyaan kuesioner. Sumber: Instagram.com (diakses April 2018).

\section{Budaya siber pada media sosial instagram}

Nasrullah menguraikan bahwa budaya siber atau cyberculture secara sederhana melihat bagaimana budaya itu berada di ruang siber. Dalam buku berjudul Komunikasi Antar Budaya di Era Budaya Siber [7] bahwa internet merupakan ruang di mana budaya yang terjadi itu diproduksi, didistribusikan, dan dikonsumsi. Media sosial juga bisa dilihat sebagai medium tempat budaya siber berada dan melalui media sosial juga dapat diketahui artefak budaya siber itu berkembang. Dengan demikian, melihat budaya siber dan media sosial harus diawali dengan sebuah konsep atau sudut pandang bahwa media sosial merupakan produk dari budaya dan sekaligus sebagai produser dari budaya itu sendiri [8].

Perkembangan teknologi internet saat ini membentuk kebudayaan baru dalam berkomunikasi dan berinteraksi. Keberadaan media sosial sebagai perangkat teknologi baru juga merupakan entitas yang memberikan kontribusi dalam kemunculan budaya siber. Begitu pula dengan Instagram. Berbagai konten visual yang disajikan pada media sosial Instagram dengan berbagai fitur yang ditawarkan, membentuk fenomena-fenomena sosial di masyarakat. Dimana sebuah visual foto yang telah lama ada di dunia nyata, kemudian terdistribusikan secara massal di internet dan bisa diakses melalui perangkat teknologi oleh semua orang kapanpun dan dimanapun. Visual foto produk fashion sebelumnya sudah ada di media konvensional nyata seperti majalah, namun saat ini visual foto tersebut dapat diakses oleh masyarakat luas di internet dan berkembang menjadi sebuah trend. Selain itu, peran media sosial juga saat ini memberikan ruang dalam pembentukan konsep diri setiap individu.

Kemajuan media sosial Instagram saat ini membentuk sebuah budaya populer di masyarakat. Adanya istilah selebgram merupakan salah satu wujud nyata dari budaya populer tersebut. Beragamnya bentuk visual yang menjadi konten dalam setiap posting-an Instagram juga menjadi trendyang dapat dilakukan oleh setiap orang. Visualisasi foto OOTD (outfit of the day) oleh selebgram dalam mempromosikan sebuah produk fashion dianggap mampu menciptakan trend konsep diri dalam berbusana, sehingga lebih menarik ketika dipandang (Gambar 6).

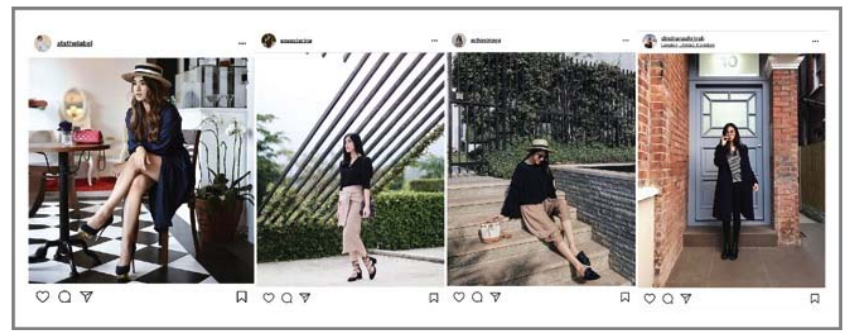

Gambar. 6. Visualisasi foto OOTD (outfit of the day) selebgram.Sumber: Instagram.com (diakses Mei 2018)

Visual fto OOTD (Outfit of The Day) sebagai eksistensi diri Salah satu fenomena dalam perkembangan kemajuan teknologi internet, berbagai perangkat pintar seperti telepon genggam, serta budaya siber saat ini adalah selfie atau foto diri. Kata ini resmi menjadi kata baru yang dimasukkan dalam kamus Oxford English Dictionary dan diartikan sebagai 'A photographic self-portrait; esp. one taken with a smartphone or webcam and shared via social media' atau secara sederhana diartikan sebagai foto diri dan disebarkan melalui media sosial.

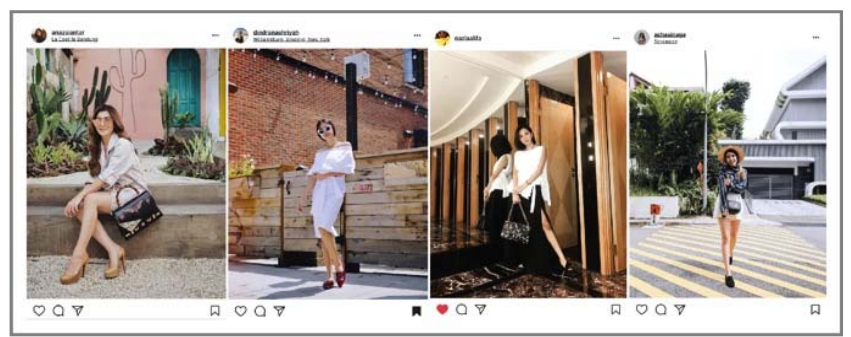

Gambar. 7. Visualisasi foto OOTD (outfit of the day) selebgram dalam mempromosikan produk fashion. Sumber: Instagram.com (diakses Mei 2018).

Fenomena foto diri ini semacam budaya visual yang muncul dan terjadi di media sosial. Para pengguna seolah-olah memiliki sebuah praktik kebudayaan baru terkait koneksitas mereka terhadap media sosial. Analisis terhadap foto diri tidak hanya dapat dilihat dari aspek wajah dan ekspresi serta gaya yang ditampilkan saja, melainkan harus melibatkan suasana, momen, bangunan, tempat atau lingkungan yang menjadi latar dari sebuah foto diri. Begitu pula dengan tampilan sebuah foto OOTD (outfit of the day) yang ditampilkan oleh seorang selebgram. OOTD berkembang menjadi budaya populer di masyarakat karena dapat dilakukan oleh siapapun. Menurut Haryanto [9] bahwa budaya populer dapat didefinisikan ke dalam empat macam. Pertama, budaya populer adalah kebudayaan yang disukai banyak orang. Kedua, kerja kebudayaan inferior. Ketiga, kerja kebudayaan yang dimaksud untuk meraih simpati banyak orang, dan keempat adalah kebudayaan yang dibuat sekelompok orang untuk diri mereka sendiri. Berdasarkan pengertian budaya populer tersebut, maka OOTD termasuk dalam budaya populer karena memenuhi keempat macam definisi tersebut. Selain itu, OOTD dapat menjadi salah satu bentuk ekspresi dan aktualisasi diri lewat pakaian yang dikenakan, serta menjadi ajang bagi seseorang untuk menunjukkan bahwa dirinya adalah pribadi yang fashionable setiap harinya. 
Visual foto OOTD yang ditampilkan oleh selebgram dalam mempromosikan produk fashion(Gambar 7) dinilai sesuai dengan insight wanita. Berpose selayaknya seorang model dengan perpaduan busana yang matching di sebuah situasi tertentu menjadi keinginan setiap wanita. Situasi latar belakang foto yang memperlihatkan kegiatan yang sedang dilakukan seperti liburan, jalan-jalan (hangout), menambah nilai ekstetika pada tampilan foto diri tersebut. Foto OOTD juga merupakan bentuk upaya representasi diri di media sosial, sebuah upaya untuk dianggap atau eksis dalam sebuah jaringan.

Fenomena visual foto OOTD tersebut kemudian dimanfaatkan oleh para pemasar untuk mempromosikan produknya. Hal tersebut karena yang ditampilkan pada sebuah foto OOTD yang diunggah mampu menjadi bahan perbincangan di media sosial. Dalam dunia pemasaran digital, dikenal dengan istilah engagement rate, yakni tingkatan keterlibatan dan interaksi followers. Selain itu, adanya trend visual foto OOTD membuat proses komunikasi dan promosi yang dilakukan bisa terjadi secara dua arah. Dalam hal ini, tidak hanya selebgram yang berpose menggunakan produk fashion tersebut dalam sebuah tampilan foto OOTD. Namun, masyarakat konsumen pun dapat melakukan hal yang sama di akun media sosial Instagramnya masing-masing (Gambar 8). Hal itu secara tidak langsung membuat masyarakat konsumen juga turut mempromosikan produk fashion tersebut.

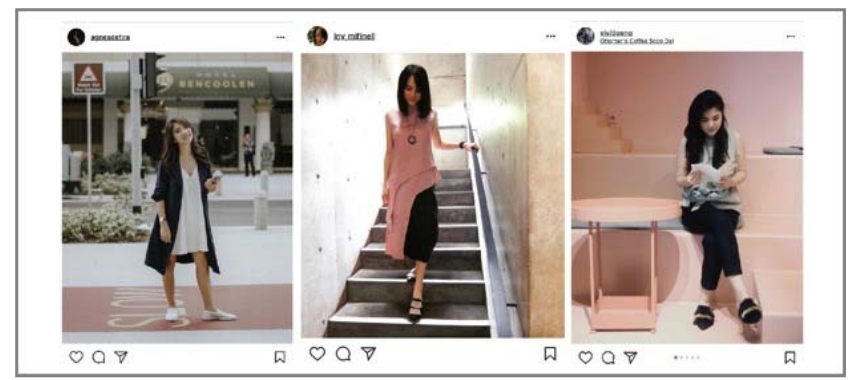

Gambar. 8. Visualisasi foto OOTD (outfit of the day) oleh konsumen wanita. Sumber: Instagram.com (diakses Mei 2018).

Seorang pengguna media sosial juga dapat menjadi seorang endorser hanya dengan menampilkan visual produk dari sebuah merek dalam tampilan visual foto dirinya. Realitas sosial dalam dunia siber ini menunjukkan bahwa kekuatan foto diri adalah artefak kebudayaan yang dapat ditafsirkan dari berbagai sudut pandang pemikiran. Dalam hal ini, media sosial merupakan arena untuk menampilkan foto diri dan pengguna mendapatkan timbal balik dari publikasi tersebut.

\section{Citra diri selebgram dalam membentuk persepsi}

Brand endorser atau dikenal juga dengan istilah Selebgram, istilah itu merujuk pada kata 'selebritis' dan 'Instagram' dimana berarti orang yang terkenal layaknya selebritis di Instagram. Orang-orang tersebut bisa dari kalangan artis, blogger, vlogger, ataupun kalangan biasa yang mempunyai banyak followers sehingga menjadi terkenal di situs jejaring sosial tersebut. Seperti yang diungkapkan oleh Soesatyo [10] brand endorser merupakan figur pendukung dalam komunikasi pemasaran, serta harus bisa menyelaraskan dirinya dengan citra produk yang dibawakan, sehingga penggunaan brand endorser juga menjadi salah satu faktor penting dalam meningkatkan daya beli konsumen. Adanya perubahan budaya visual yang dipengaruhi oleh kemajuan teknologi di masyarakat mengubah cara pandang masyarakat terhadap tampilan sebuah iklan produk, terutama produk fashion. Trend dan gaya hidup seorang selebgram dinilai mampu menjadi faktor yang mempengaruhi persepsi masyarakat terhadap sebuah brand. Bagaimana sebuah brand tersebut dapat memiliki tingkat asosiasi yang sesuai, sehingga pada akhirnya akan menentukan tingginya angka penjualan produk.

Visual foto OOTD selebgram yang mempromosikan sebuah produk fashion dinilai lebih realistis. Selebgram yang bukan berasal dari kalangan artis papan atas, membentuk adanya persepsi di benak konsumen wanita untuk agar dirinya dapat terlihat seperti tampilan visual tersebut adalah hal yang memungkinkan, baik dilihat dari proporsi tubuh selebgram, maupun kemampuannya dalam memadupadankan busana. Beda halnya ketika yang ditampilkan adalah seorang model professional ataupun artis papan atas yang dinilai terlalu ideal. Secara psikologis, konsumen wanita akan merasa bahwa untuk mendapatkan penampilan seperti itu, bukanlah sesuatu hal yang mudah digapai. Selain itu, dalam visual foto OOTD selebgram, ditampilkan pula kegiatan yang sedang dilakukan serta lokasi pengambilan foto (Gambar 9, 10, dan 11). Hal itu menciptakan persepsi konsumen wanita yang merasa bahwa visual yang ditampilkan tersebut sesuai dengan aktivitas kesehariannya, sehingga dirasa lebih natural.

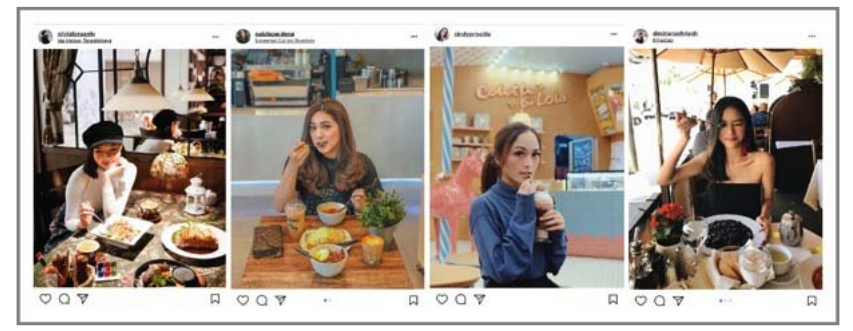

Gambar. 9. Visualisasi foto OOTD (outfit of the day) selebgram saat kuliner.Sumber: Instagram.com (diakses Mei 2018).

Gaya hidup dan citra diri selebgram yang selalu up to date, membuat sebuah produk fashion yang digunakan oleh seorang selebgram dianggap hits dan kekinian. Hal itu semakin menarik minat konsumen wanita untuk membeli produk fashion tersebut agar selalu terlihat up to date. Mengingat salah satu insight dari generasi muda saat ini adalah FOMO (fear of missing out), suatu gejala sosial yang membuat seseorang tidak ingin ketinggalan informasi dan momen dari lingkungan pergaulannya.

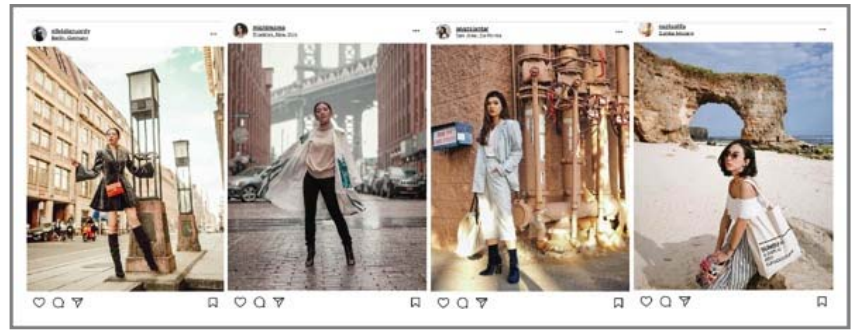

Gambar. 10. Visualisasi foto OOTD (outfit of the day) selebgram saat travelling Sumber: Instagram.com (diakses Mei 2018).

Kredibilitas seorang selebgram mampu mempengaruhi kepercayaan konsumen wanita dalam menilai sebuah produk fashion. Mengingat transaksi yang dilakukan adalah tranksaksi virtual secara online, yang mana konsumen tidak lagi dapat memegang, merasakan, atau mencoba barang tersebut terlebih dahulu. Oleh karena itu, sangat penting bagi sebuah brand dalam memilih selebgram yang tepat untuk mempromosikan produknya. Ada beberapa faktor yang menjadi dimensi pengukuran keefektivitasan pemilihan seorang brand endorser menurut Shimp [11], meliputi kredibilitas, daya tarik, dan kecocokan. Pemilihan selebgram yang tepat akan berpengaruh terhadap pembentukkan persepsi konsumen yang efektif.

\section{Fan culture pada media sosial Instagram}

Budaya penggemar merupakan realitas sosial yang harus didekati sebagai apa yang disebut essential cultural negotiation[12]. Realitas penggemar ini muncul dari adanya emosi seseorang atau komunitas ketika mengkonsumsi produk, tetapi patut dicatat bahwa di balik itu semua ada nilai-nilai yang muncul dari apa atau siapa yang menjadi idola mereka [13]. Kemajuan teknologi memberikan perubahan berarti dari sekedar mengkonsumsi dan memproduksi 
budaya penggemar. Jenkins mengenalkan apa yang disebut dengan the cosmopedia yang meminjam istilah Pierre Levy tentang knowledge Space[14]. Istilah ini merujuk pada lingkungan kesadaran dari individu bahwa kemajuan teknologi serta internet memberikan kesadaran bagi individu dalam melakukan pilihan termasuk bagaimana mereka mengkonsumsi dan memproduksi.

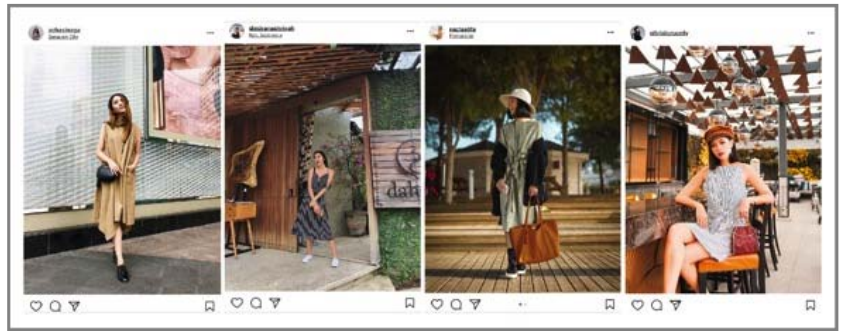

Gambar. 11. Visualisasi foto OOTD (outfit of the day) selebgram saat hangout. Sumber: Instagram.com (diakses Mei 2018).

Adanya kesadaran dan hubungannya dengan teknologi internet secara khusus memberikan redefinisi terhadap apa yang dimaksud dengan budaya penggemar. Salah satunya di media sosial seseorang tidak perlu menjadi public figur untuk menjadi idola dan memiliki penggemar. Perkembangan teknologi internet, juga membentuk suatu budaya siber yang mempengaruhi pola pikir masyarakat, khususnya generasi millennial dan Z. Banyak artikel dan penelitian yang menyebutkan bahwa saat ini cita-cita mereka bukan lagi menjadi seorang dokter, polisi, atau profesi umum lainnya. Melainkan, menjadi seorang influencer, vlogger, blogger, ataupun selebgram. Profesi yang 10 tahun lalu belum terpikir akan ada. Hal tersebut kemudian membentuk sebuah budaya populer yang dipengaruhi budaya penggemar dalam masyarakat siber. Mengidolakan seorang selebgram dan adanya keinginan diri untuk menjadi idola dengan mendapat banyak "like" dan"follower"pada media sosial Instagram merupakan salah satu wujud perkembangan budaya penggemar tersebut. Kuliner, travelling, fashion, dan menjadi trendsetter adalah beberapa faktor yang menjadi insight sebagian besar generasi muda saat ini. Budaya instan dalam proses komunikasi yang ditampilkan oleh selebgram dalam meraih gaya hidup tersebut, mempengaruhi persepsi generasi muda dalam menentukan keinginan profesi.

Budaya penggemar juga berkembang dengan betapa pentingnya sebuah "Like" dan "Follower" di era digital ini. Semakin banyak follower seorang selebgram, maka akan semakin berpengaruh dirinya di media sosial tersebut. Begitu pula dalam visual foto OOTD selebgram dalam mempromosikan produk fashion. Semakin banyak 'like' yang didapat oleh tampilan foto tersebut, maka akan mempengaruhi kepercayaan konsumen wanita akan kualitas produk serta menimbulkan ketertarikan dan minat beli. Hal itu karena adanya anggapan bahwa model fashion tersebut disukai oleh banyak orang. Dengan kata lain, dengan membeli produk fashion tersebut akan membuat penampilan wanita menjadi lebih menarik dan terlihat seperti sosok selebgram yang diidolakannya.

\section{Male Gaze pada media sosial Instagram}

Dalam sebuah visual foto OOTD (outfit of the day) oleh selebgram yang mempromosikan produk fashion wanita juga mengandung unsur male gaze(Gambar 12). Dalam hal ini bagaimana wanita memandang wanita lain, untuk membuat dirinya menarik di mata pria. Visual foto yang ditampilkan oleh selebgram secara keseluruhan memiliki daya tarik secara visual, baik dari segi fisik maupun gaya berbusana. Wajah yang cantik dan bentuk tubuh yang ideal, serta gaya berbusana yang menarik, membuat konsumen wanita menjadikan sosok selebgram tersebut sebagai role model dalam berpenampilan. Hal tersebut sesuai dengan sifat dasar wanita yang sekaligus melandasi motivasinya yakni ingin mendapat perhatian sosial, baik itu dari pria maupun wanita lain yang ada di lingkungannya.

Adanya keinginan untuk dapat terlihat seperti penampilan wanita lain dalam foto tersebut agar mendapat perhatian pria, menumbuhkan minat beli pada benak konsumen wanita. Hal itulah yang membuat mengapa visualisasi foto dengan menggunakan selebgram dinilai lebih efektif dalam strategi promosi sebuah produk fashion.

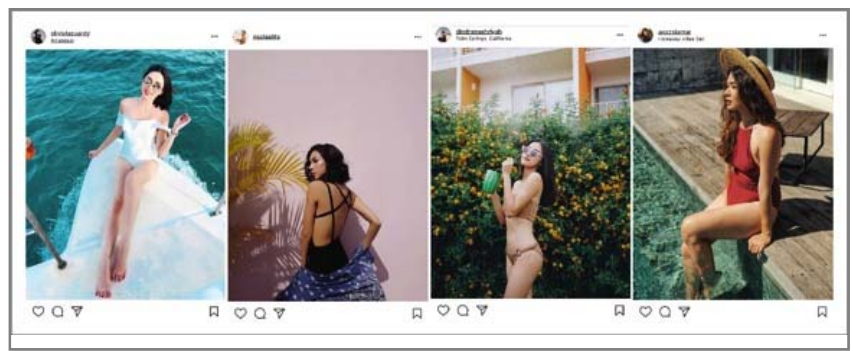

Gambar. 12. Male gaze dalam visualisasi foto OOTD (outfit of the day) selebgram. Sumber: Instagram.com (diakses Mei 2018).

\section{KESIMPULAN}

Kehadiran teknologi membawa perubahan besar dalam kebudayaan masyarakat, termasuk di dalamnya adalah trend pemasaran digital. Sebagai produk yang paling diminati dalam bertranksaksi online, produk fashion terus mengembangkan strategi promosinya dengan memanfaatkan media sosial Instagram. Salah satunya dengan menggunakan jasa seorang selebgram untuk menampilkan visual foto OOTD (outfit of the day) dalam mempromosikan produk fashion. Perkembangan teknologi yang membentuk budaya populer di masyarakat siber menjadi faktor utama adanya ketertarikan akan visualisasi foto OOTD tersebut sebagai bentuk eksistensi diri individu. Adanya fenomena foto diri yang menjadi sebuah tren di masyarakat, dikaitkan dengan citra diri serta fan culture yang terjadi pada fenomena selebgram membentuk persepsi positif dalam benak konsumen wanita. Selain itu, adanya unsur male gaze dalam sebuah tampilan visual foto OOTD selebgram wanita juga dinilai mampu menjadi daya tarik yang menentukan minat pembelian sebuah produk fashion. Oleh karena itulah, visualisasi foto selebgram dalam sebuah tampilan foto OOTD (outfit of the day) dinilai lebih efektif dalam menciptakan persepsi positif di benak wanita yang menjadi target konsumen sebuah merek produk fashion di era industri 4.0 sekarang ini.

\section{DAFTAR PUSTAKA}

[1] Riset Konsumen Belanja Online, data diperoleh dari situs internet:

[2] https://lifestyle.kompas.com/read/2018/03/22/155001820/80persen konsumen-belanja-online-orang-muda-danwanita(diunduh pada tanggal 1 Mei 2018)

[3] Riset Promosi di Media Sosial dan Prospek Selebgram, data diperoleh dari situs internet: https://www.fimela.com/lifestylerelationship/dana-promosi-di-medsos-meningkat-2018-masihjadi-tahun-yang-bagus-untuk-para-selebgram-180215r.html (diunduh pada tanggal 1 Mei 2018)

[4] Nasrullah, Rulli. 2015. Media Sosial. Bandung: Simbiosa Rekatama Media.

[5] Saxena, S. 2014. "Social Media can be Organized in 6 Clear Categories." Data diperoleh dari situs internet: http://www.easymedia. in/social-media-can-organized-6clear-categories/

[6] Mulvey, Laura. 1975. Visual Pleasure and Narrative Cinema.

[7] Berger, John. 1986. Ways of Seeing. London: BBC and Penguin.

[8] Nasrullah, Rulli. 2012. Komunikasi Antar Budaya di Era Budaya Siber. Jakarta: Prenada Media.

[9] Bell, D. 2001. An Introduction to Cybercultures. New York: Routledge.

[10] Haryanto, Ignatius. 2006. Aku Selebriti maka Aku Penting. Yogyakarta: Penerbit Bentang. 
[11] Soesatyo, N dan Julivan R. 2013. Analisa Credibility Celebrity Endorser Model: Sikap Audience terhadap Iklan dan Merek Serta Pengaruhnya Pada Minat Beli "Top Coffee”. Jurnal Manajemen Pemasaran Vol. 1.

[12] Shimp, T. A. 2003. Periklanan Promosi. Jakarta: Erlangga.
[13] Hills, M. 2002. Fan Cultures. New York: Routledge.

[14] Sassatelli, R. 2007. Consumer Culture: History, Theory and Politics. Los Angeles: SAGE Publications, Ltd.

[15] Jenkins, H. 2006b. Fans, Bloggers, and Gamers. New Jersey: New York University Press. 